\title{
EFFECT OF FOOD INTAKE, FASTING, DEUTECTOMY AND ENVIRONMENTAL TEMPERATURE ON SATURATED AND UNSATURATED FATTY ACID DISTRIBUTION IN THE BLOOD PLASMA OF COCKERELS IN THE FIRST WEEK AFTER HATCHING
}

\author{
E. BARANYIOVÁ, S. STANDARA \\ Department of Physiology, University of Veterinary Science, 61242 Brno, \\ Veterinary Research Institute, 62132 Brno
}

Received April 8, 1980

\begin{abstract}
Baranyiová E., S. Standara: Effect of Food Intake, Fasting, Deutectomy and Environmental Temperature on Saturated and Unsaturated Fatty Acid Distribution in the Blood Plasma of Cockerels in the First Week after Hatching. Acta vet. Brno, 50, 1981: 43-47.

The effect of food intake, fasting; ambient temperatures of $18^{\circ} \mathrm{C}$ and $35^{\circ} \mathrm{C}$ and deutectomy on the distribution of saturated and unsaturated fatty acids in the blood plasma of cockerels was investigated in 200 birds aged 1 to 5 days. Total plasma fatty acids were determined by gas chromatography.

In newly hatched cockerels the quantitatively most important $\left(\mathrm{C}_{14}-\mathrm{C}_{20}\right)$ saturated fatty acids accounted for $68.2 \pm 4.2 \%$ and unsaturated acids for $27.1 \pm$ $\pm 4.7 \%$ of total fatty acids.

This distribution changed considerably within the first week after hatching in that the saturation of fatty acids decreased at a rate obviously dependent on the onset of food intake: it started to change later in fasted than in fed birds. Environmental temperature and deutectomy did not affect these changes.
\end{abstract}

Fatty acids $\left(C_{14}-C_{20}\right)$, age-dependent changes, saturation.

Fatty acids serve mainly as an energy source to the body. Small amounts of fatty acids (FA) are used in addition for other purposes such as membrane formation or prostaglandin synthesis (Lindsay 1975). Data on their role in lipid metabolism of birds are rather scarce; their contribution to egg lipids of the domestic fowl and other avian species were studied e. g. by Christie and Moore (1972). The bulk of fatty acids in body fats of various migrating avian species was found to consist of oleic $(36 \%)$ and palmitic $(21 \%$ ) acids (Caldwell 1973). In depot fats of adult fowls $69 \%$ unsaturated and $31 \%$ saturated fatty acids was found (Feigenbaum and Fisher 1959).

There are no data, however, on the effects of age, fasting, and various ambient temperatures on the distribution of saturated and unsaturated fatty acids in the blood plasma of chickens. We therefore investigated this distribution in newly hatched cockerels and followed its development with age in fed and fasted birds and the effects of deutectomy and two ambient temperatures.

\section{Materials and Methods}

In the experiment 200 newly hatched Shaver Starcross cockerels were employed. The birds were kept and treated as previously described (Baranyiová, Standara 1980).

Five birds each of all experimental groups were blood-sampled invariably at the same time of the day after minimum handling on days $1,2,3,4$ and 5 . The blood plasma samples for determination 
of total fatty acids were processed according to Hammarstrand (1966). The methyl esters of fatty acids were purified on Florisil (Johns on and Daven port 1971). Gas chromatograph Chrom IV (LP Praha) equipped with a flame ionization detector and flash heater temperature of $235^{\circ} \mathrm{C}$ was used for determination of methyl esters of fatty acids. A stainless steel column $(2.5 \mathrm{~m} \times 3 \mathrm{~mm})$ packed with $5 \%$ DEGS on Inerton AW-DMCS (100-125 mesh) (Lachema Brno, CSSR) was run isothermically at $195^{\circ} \mathrm{C}$. Qualitative analysis was based on relation between the elution time and number of carbon atoms in the molecules of individual homologues (Purnell 1967; Barvír et al. 1968), for quantitative analysis the method of internal normalization was employed (Forman 1970). The contents of NEFA $\left(C_{8}-C_{24}\right)$ are expressed as $\% \mathrm{w} / \mathrm{v}$ of total fatty acids. Results were statistically evaluated by Student's t-test.

\section{Results}

In the blood plasma of newly hatched chickens $68.2 \pm 4.2 \%$ saturated and $27.1 \pm 4.7 \%$ unsaturated fatty acids was found (Fig 1). As soon as 24 hours later a sharp decrease $(P<0.001)$ of saturated fatty àcids and an increase $(P<0.01)$ of unsaturated fatty acids occurred $(33.1 \pm 1.0$ and $54.7 \pm 2.2 \%$ respectively) and this distribution of fatty acids remained practically unchanged until day 5 , with significantly more unsaturated acids $(P<0.001 ; P<0.001 ; P<0.001$; and $P<0.02)$ in the plasma of intact fed chickens. A similar distribution of fatty acids was also found in intact chickens exposed to $18^{\circ} \mathrm{C}$ for one hour $(P<0.001$; $P<0.001 ; P<0.01 ;-)$. This pattern of development was also observed in deutectomized birds, a significantly larger proportion of unsaturated fatty acids being observed at both temperatures on days 3,4 and $5(P<0.001 ; P<0.01$; $P<0.001$ ) (Fig. 2).

In the plasma of fasted intact chickens (Fig. 3), kept at $35^{\circ} \mathrm{C}$ the proportions of the two groups of fatty acids began to change slowly between days 2 and 3 so that a smaller proportion of saturated $(34.3 \pm 1.6 \%$ ) and a larger proportion of unsaturated $(52.4 \pm 1.7 \%$ ) FA vas found on day 5 . Almost the same values

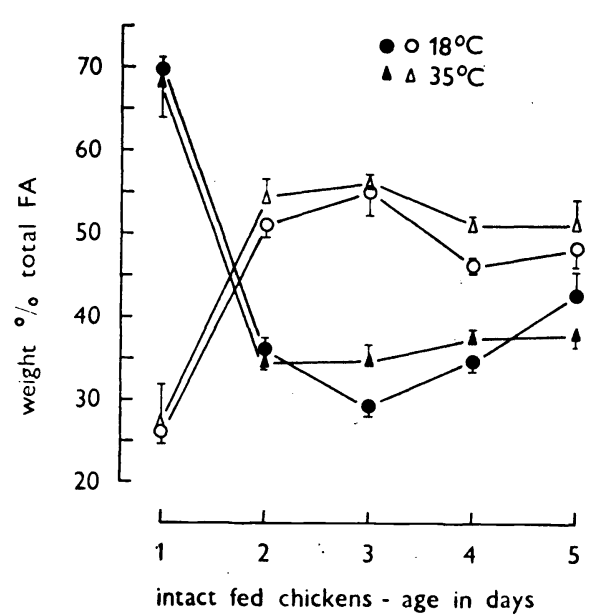

Fig. 1

Distribution of saturated (closed symbols) and unsaturated (open symbols) fatty acids in the blood plasma of intact fed chickens

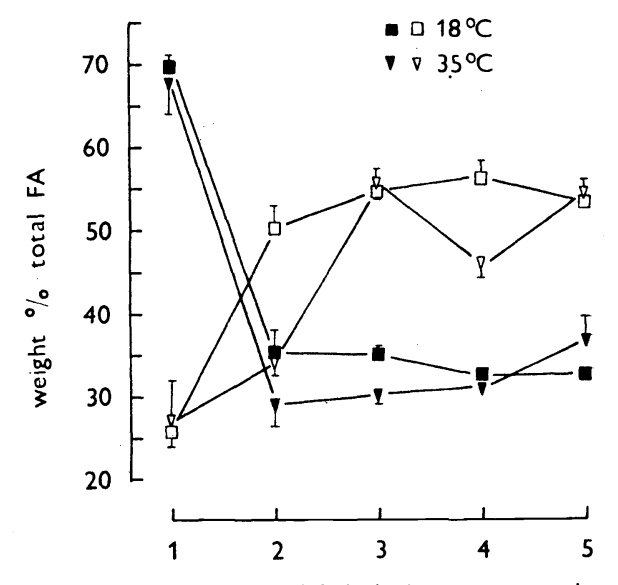

Fig. 2

Distribution of saturated (closed symbols) and unsaturated (open symbols) fatty acids in the blood plasma of deutectomized fed chickens 


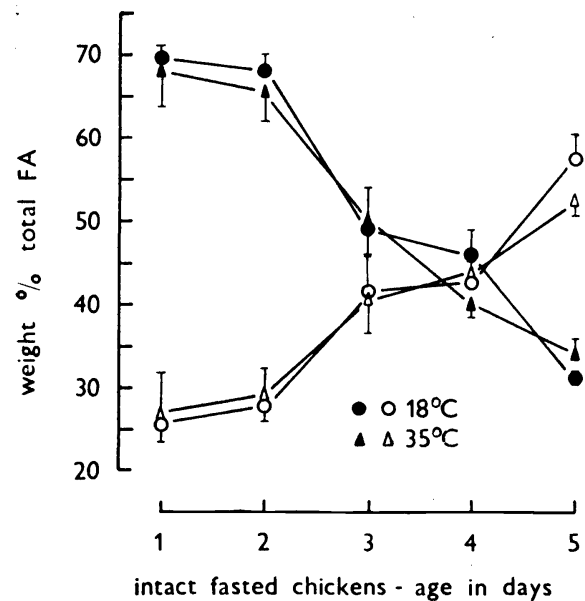

Fig. 3

Distribution of saturated (closed symbols) and unsaturated (open symbols) fatty acids in the blood plasma of intact fasted chickens

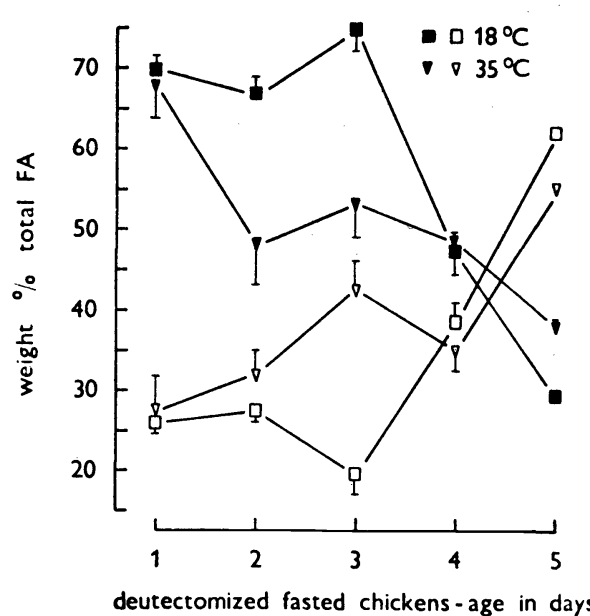

Fig. 4

Distribution of saturated (closed symbols) and unsaturated (open symbols) fatty acids in the blood plasma of deutectomized fasted chickens

were obtained in birds exposed to $18^{\circ} \mathrm{C}$. In deutectomized fasted cockerels kept at $35^{\circ} \mathrm{C}$ the development was similar as in the previous group. In deutectomized fasted birds exposed to $18{ }^{\circ} \mathrm{C}$ the shift in the proportions of FA began to occur between day 3 and 4 (Fig. 4 ).

\section{Discussion}

In newly hatched chickens the quantitatively most important saturated fatty acids $\left(\mathrm{C}_{14}-\mathrm{C}_{20}\right)$ averaged $68 \%$ and the unsaturated ones about $27 \%$. However, using the data reported by Christie and Moore (1972) for triglyceride composition of Shaver Starbro and Shaver Starcross eggs we calculated that in their study the reverse was the case: saturated fatty acids accounted for 33.9 and $36.1 \%$ and unsaturated acids for $66.1 \%$ of total fatty acids, respectively.

Similarly, in depot fats of adult hens Feigen baum and Fisher (1959) found $32 \%$ saturated and $67 \%$ unsaturated fatty acids. Nevertheless, there is evidence to indicate that intensive transformation and synthesis of lipid components occurs during the embryonic development (Budowski et al. 1961; Noble and Moore 1964, 1967) and that the developing embryo preferentially absorbs from the yolk a phosphatidyl ethanolamine fraction that is relatively rich in polyunsaturated docosahexaenoic acid (Noble and Moore 1965). Moreover, the fatty acid synthetase activity was found to be low in chick liver during the entire embryonic development (Joshi and Sidbury 1975).

Our finding of a larger proportion of saturated fatty acids along with a smaller proportion of unsaturated acids immediately after hatching may reflect specific metabolic events in the embryo leading to exhaustion of its unsaturated fatty acid supplies.

This view is further supported by the fact that having changed significantly 
during the first 24 hours after hatching the proportions of saturated and unsaturated fatty acids in all groups of fed birds became similar to the values reported by Feigenbaum and Fisher (1959) for adult fowls. Also the fatty acid synthetase increased by about three-fold on hatching and thereafter in fed, newly hatched chickens by about 35-fold, over the basal embryonic activity (Joshi and Sidbury 1975).

The data on distribution of saturated and unsaturated fatty acids in blood plasma of chickens in the first posthatching week reported here provide the basic information about the distribution and movement of these metabolites in the internal environment in the early post-incubation period of the domestic fowl.

In the two groups of fasted cockerels the shift in the proportions of saturated and unsturated fatty acids did occur too, though later, and reached values similar to those found in the fed birds not until day 5 . This finding indicates that the mechanisms involved in induction of post-hatching fatty acid synthesis begin to operate at or in consequence of hatching and are therefore not related to food intake only. This conclusion is supported by data of Joshi and Sidbury (1975). Exposure to $18{ }^{\circ} \mathrm{C}$ did not affect the changes in FA saturation in intact cockerels. In deutectomized fasted birds the change in saturation of plasma fatty acids was delayed as compared with intact fasted birds.

In conclusion in can be stated that saturation of fatty acids in the blood plasma of chickens decreases considerably within the first five post-hatching days, its rate depending on the onset of food intake. This process was not affected by either environmental temperature or deutectomy.

\section{Vplyv príjmu potravy, hladovania, deutektómie a teploty prostredia na obsah nasýtených a nenasýtených mastných kyselín $v$ krvnej plazme kurčiat v prvom týždni po vyliahnutí}

Na 200 kohútikoch línie Shaver Starcross sme sledovali vplyv príjmu potravy, hladovania a teploty prostredia $\left(18{ }^{\circ} \mathrm{C}\right.$ a $\left.35^{\circ} \mathrm{C}\right)$ na obsah plazmatických nasýtených a nenasýtených mastných kyselín $(\mathrm{MK})$ od 1 . do 5 . dňa po vyliahnutí. Celkové mastné kyseliny sme stanovovali pomocou plynovej chromatografie.

U kurčiat po vyliahnutí činil podiel kvantitatívne najvýznamnejších $\left(\mathrm{C}_{14}-\mathrm{C}_{20}\right)$ MK nasýtených $68.2 \pm 4.2 \%$, nenasýtených $\mathrm{MK} 27.1 \pm 4.7 \%$.

V priebehu prvého týžznna po vyliahnutí sa však tento podiel $\mathrm{MK}$ v plazme podstatne zmenil, a to tak, že saturácia mastných kyselín klesla. Rýchlost' tejto zmeny je zrejme závislá na zahájení príjmu potravy; u hladujúcich kurčiat sa objavila neskôr ako u kŕmených. Teplota prostredia ani deutektómia ju však neovplyvnila.

\section{Влияние приема пищи, голодания, дейтектомии и температуры окружающей среды на содержание насыщенных и ненасыщенных жирных кислот в кровяной плазме цыплят на первой неделе}

Ha 200 петушках линии Shaver Starcross нами проводились наблюдения за влиянием приема пищи, голодания и температуры окружающей среды на содержание плазматических насыщенных и ненасыщенных жирных кислот с первого по пятый дни после вылупливания. Общие жирные кислоты нами были определены с помощью газовой хроматографии. 
У цыплят после вылупления доля качественно самых значимых (С14(20) насыщенных жирных кислот составляла $68,2 \pm 4,2 \%$, ненасыщенных жирных кислот $27,1 \pm 4,7 \%$.

В течение первой недели после вылупления она, однако, существенно меняется, а именно так, что их сатурация понижается. Скорость данного изменения зависит от начала приема пищи; температура окружающей среды на нее не оказывает влияния, у голодных она появляется позже, чем у кормленных цылят.

\section{References}

BARANYIOVÁ, E. - STANDARA, S.: Effect of deutectomy, fasting and environmental temperature on free fatty acid concentration in the blood plasma of chickens in the first week after hatching. Acta vet. Brno, 49, 1980: 187-192.

BARVÍR, J. - TOŠNER, A. - SUŚILOVÁ, D.: Studie složení esterů mastných kyselin tržních jednodruhových olejů plynovou chromatografí. Prủmysl potravin 19, 1968: 48-51.

BUDOWSKI, P. - BOTTINO, N. R. - REISER, R.: Lipid transport in the laying hen and the incubating egg. Arch. Biochem. Biphys., 93, 1961: 483-490.

CALDWELL, L. D.: Fatty acids in migrating birds. Comp. Biochem. Physiol., 44B, 1973: 493-497.

CHRISTIE, W. W. - MOORE, J. H.: The lipid composition and triglyceride structure of eggs from several avian species. Comp. Biochem. Physiol., 41B, 1972: 297-306.

FEIGENBAUM, A. S. - FISHER, H.: The influence of dietary fat on the incorporation of fatty acids into body and egg fat of the hen. Arch. Biochem. Biophys., 79, 1959: 302-306.

FORMAN, L.: Plynová chromatografie mastných kyselin. Průmysl potravin, 21, 1970: 121-125.

HAMMARSTRAND, K.: Gas Chromatographic Analysis of Fatty Acids, Varian Aerograph Pbl., 9, 1966: 66-A-1000.

JOHNSON, A. R. - DAVENPORT, J. B.: Biochemistry and Methodology of Lipids, Wiley Interscience, N. Y. 1971: 348-349.

JOSHI, V. C. - SIDBURY, Jr., J. B.: Fatty acid synthesis in chick embryonic heart and liver during development. Develop. Biol., 42, 1975: 282-291.

LINDSAY, D. B.: Fatty acids as energy sources. Proc. Nutr. Soc., 34, 1975: 24-248.

NOBLE, R. C. - MOORE, J. H.: Studies on the lipid metabolism of the chick embryo. Can. J. Biochem., 42, 1964: 1729-1741.

NOBLE, R. C. - MOORE, J. H.: Metabolism of the yolk phospholipids by the developing chick embryo. Can. J. Biochem., 43, 1965: 1677-1686.

NOBLE, R. C. - MOORE, J. H.: The partition of lipid between the yolk and yolk-sac membrane during the development of the chick embryo. Can. J. Biochem., 45, 1967: 949-958.

PURNELL, H.: Plynová chromatografie, SNTL Praha 1967, pp. 463. 